\title{
is Research Square \\ Spirituality at Workplace: Role of Spiritual Leadership, Productivity, and Emotional Exhaustion
}

Ansar Abbas ( $\square$ ansar.abbas-2018@feb.unair.ac.id)

Universitas Airlangga https://orcid.org/0000-0003-4521-1920

Fendy Shuairidi

Universitas Airlangga https://orcid.org/0000-0001-9726-4720

Dian Ekowati

Universitas Airlangga https://orcid.org/0000-0001-9679-2185

\section{Aisha Anwar}

Viqar-Un-Nisa Post Graduate College Rawalpindi

Muhammad Saud

Universitas Airlangga

\section{Research Article}

Keywords: spiritual leadership, workplace spirituality, productivity, emotional exhaustion

Posted Date: May 5th, 2021

DOI: https://doi.org/10.21203/rs.3.rs-492746/v1

License: (c) (i) This work is licensed under a Creative Commons Attribution 4.0 International License.

Read Full License 


\section{Abstract}

Workplace spirituality understanding focuses upon employee's inner life that nurtures the inner life irrespective of the gender of employees. It helps to encounter stress that brings emotional exhaustion in employee and affect productivity. This study looks at the role of spiritual leadership in promoting workplace spirituality, encountering emotional exhaustion, and cultivating productivity. In educational and healthcare workplace settings, systematic sampling was used to collect the data and processed in Wrappls for path analysis. It concludes that spiritual leadership research can provide unique insight, which has not been done persistently in South Asian countries. The study concludes positive results of spiritual leadership inculcating workplace spirituality to improve organizational engagement, efficiency, and life satisfaction. Finally, the pertinent sections discuss some recommendations for future leadership scopes, science, and practice in applied contexts.

\section{Introduction}

Spiritual leadership and spirituality in the workplace are in their infancy, so in western religious theology, the theoretical understanding and ethics and values of leadership are minimal (Fry \& Cohen, 2009; Judge, Bono, Ilies, \& Gerhardt, 2002). The focus of research for identifying spiritual principles and behaviors, exploring philosophical structures and models relating to spirituality, and designing instruments for evaluating spirituality are the three primary areas of emphasis on spirituality in the workplace (Meng, 2016). However, the concentration of research studies in a few geographic regions highlights the need for research worldwide, including in the South Asian area, to ensure the theory's validity and generalizability (Mubashar, Salman, Irfan, \& Jabeen, 2017).

Ashmos and Duchon (2000) Identified workplace spirituality as the appreciation that employees have an inner life nurtured by meaningful community work. The idea of workplace spirituality has been discussed in various ways in academia, making it challenging to produce a comprehensive description in multiple ways to unravel and identify relationships of value, interconnectedness, and a sense of harmony in work life (Tischler, Biberman, \& McKeage, 2002). Thus, in the current analysis, the inner life of irrespective of the gender of employees, productivity, and workplace spirituality to predict productivity and overcome emotional exhaustions of the working community are used and examined in relation to one another. This study enables building propositions through literature review and assess the path model, it further discusses the theoretical and practical consideration of the implementation of this study.

\section{Literature Review}

The new learning organizational paradigms and accelerating patterns for workplace spirituality now seem to come together (Giacalone \& Jurkiewicz, 2010). As a result, these fields lack theoretical and empirical evidence, except for organizational theories relating to Western theological theology and practice, as well as leadership ethics and values (Blackaby \& Blackaby, 2011; Northouse, 2010). The attributes and processes for promoting this confluence are a vital problem to be addressed by different 
leadership styles, i.e., strategic leadership, leadership in empowered teams, and personal oversight (Abdullah, Alzaidiyeen, \& Aldarabah, 2009; Chen, Chen, \& Li, 2013; Hitt \& Duane, 2002; Wootton \& Horne, 2010; Worden, 2005). When a company resists making improvements to integrate workplace spirituality, transitioning to the organizational learning model seems improbable. Spiritual leadership and workplace spirituality research are in their early stages.

Spirituality leadership plays a crucial role in ethics and values, i.e., instilling and strengthening personal, team, and organizational values (Collins, 2010; Fry, 2003; Fry, Vitucci, \& Cedillo, 2005; Karadag, 2009). Leadership and ethics share a synergistic spiritual partnership because leadership ensures ethics is fundamental to leadership. The leadership's essence and the need to involve followers to achieve shared objectives foster this cooperation between the two parties. However, there is a dearth of significant academic contributions and a solid theoretical foundation for leadership ethics and values (Fry et al., 2005). Fry (2003) integrated spirituality, an ex-factor, into leadership theory and finally suggested that spiritual leadership highlights that the leaders' beliefs, attitudes, and actions are inherently empowering. Spiritual leadership, as the leaders' beliefs, attitudes, and conduct, comprises three major components, vision, hope/faith, and altruistic love. The concept refers to a positive future that instills inherent selfworth and a sense of mission in employees. Hope/faith represents the leader's conviction in the vision's viability and may bring high levels of motivation in subordinates to conduct the organizational task.

Altruistic love exhibits a set of leadership behaviors that value mutual concern and respect and generate a sense of understanding and appreciation of members of the organization, around which a positive organizational culture can be established. In the spiritual leadership model, vision provides an underlying meaning for life. When workers have hope/faith that the shared vision helps involve them in achieving future goals, they are spiritually grounded. This is the ultimate reward for workers to develop solid values and promote a positive organizational vision (Chen \& Yang, 2012; Fry \& Cohen, 2009; Fry, Latham, Clinebell, \& Krahnke, 2017; Yang \& Fry, 2018). Spiritual leadership is a value-based, holistic approach to leadership that focuses on the social connections between leaders, followers, and coworkers to promote the creation and maintenance of an organizational culture that positively impacts organizational success and effectiveness by capturing business participants' behaviors, desires, and underlying motives, all of which contribute to individual and organizational effectiveness.(Fry \& Nisiewicz, 2013; Fry et al., 2005).

\section{Spiritual leadership and Workplace spirituality}

Over the last few decades, interest in spirituality and religion in the workplace has grown, attracting both academics and practitioners (Benefiel, Fry, \& Geigle, 2014). Some argue that this is because society is now looking for spiritual alternatives that facilitate turbulent social and business changes, that fundamental changes in values have brought a growing social and spiritual revival globally, and that the interest in Eastern ideologies has resurrected spiritual aspirations globally (Cash \& Gray, 2000; Hood, 2005; Peltonen, 2017). Others argue that our relationship with work is gradually becoming an essential part of our self-concept, having a significant impact on the quality of our lives both at work and at home. 
Employees now actively seek opportunities for meaningful activities and a sense of community in the workplace, as they spend a growing amount of time there (Collins, 2010; Hill \& Edwards, 2013; Oh \& Wang, 2020; Sohail et al., 2019).

Some have argued that spirituality in the workplace offers solutions to complex contemporary challenges arising from significant changes (e.g., downsizing, reengineering, and dismissal). Employees now see themselves as expendable resources because of the mistrust and diminishing view of the work that has resulted from these organizational changes. The positive effect of workplace spirituality and spiritual leadership can be counterbalanced by those changes which have caused the demoralization and spiritual disorientation of employees (Abdullah et al., 2009; Afsar, Badir, \& Kiani, 2016; Freeman, 2011; Peltonen, 2017; Sani, Soetjipto, \& Maharani, 2016; Sholikhah, Wang, \& Li, 2019).

Leaders face a moral threshold that they must cross to solve these problems (blinded for review 1) successfully; this view advocates for a shared leadership style founded on spiritual values with which workers can identify. This study uses the term "spirituality" to refer desire for self-transcendence and the resulting sense of interconnectedness with all things in the universe. Most frequently, spirituality is regarded as fundamentally personal, although it can exist or manifest in groups and organizations (Woods, 2007). From this viewpoint, a religious spirituality is an entity that has grown and developed over time through the spiritual experiences of one or more founders, providing the basis for leadership based on the religions and practices (Peltonen, 2017; Rouhoma, Dhar, Ali, \& Osman, 2018).

Spiritual leadership theory is purposefully spiritual to be applicable in religious and non-religious organizations, even though both are founded on a vision of service to others through compassion or other-centeredness (Sun \& Hodge, 2012). Spiritual leadership is seen as essential for meeting the basic needs of both leaders and followers for spiritual well-being through calling and membership; for creating vision and value congruence at the person, an empowered team, and organization levels; and, finally, for fostering higher levels of employee well-being, organizational commitment, financial performance, and sociability that result in workplace spirituality (Lewis \& Geroy, 2000; Nahardani, Ahmadi, Bigdeli, \& Arabshahi, 2019; Sohail et al., 2019; Stylianou \& Zembylas, 2019; Timmins \& Martin, 2019).

$\mathrm{H}_{1}$ : Workplace spirituality is an outcome of spiritual leadership.

\section{Workplace Spirituality and productivity}

Creating a vision in which leaders and followers feel a sense of calling for their lives to have meaning and intent and to make a difference; Establishing an organizational culture founded on altruistic love values where leaders and followers have a sense of membership and belonging and feel understood and valued (Fry, 2003; Giacalone, Jurkiewicz, \& Fry, 2005). Spiritual Leadership, altruistic love in spiritual leadership, is described as "a sense of wholeness, peace, and well-being created by self-care, concern, and appreciation (Freeman, 2011; Fry, 2003; Fry \& Cohen, 2009). Spiritual leadership and related research have shown that it predicts various important individual and organizational outcomes in multiple 
countries and cultures (Fry \& Cohen, 2009). These include being positively related to organizational commitment (Rouhoma et al., 2018), job satisfaction (Sani et al., 2016), altruism, awareness, self-career management (Lewis \& Geroy, 2000), job participation (Seong \& Hong, 2018), retention (ArmstrongStassen \& Schlosser, 2011), life satisfaction and work unit productivity (Benefiel, 2005; Chen et al., 2013; Fry \& Nisiewicz, 2013; Hunsaker, 2019).

$\mathrm{H}_{2}$ : workplace spirituality brings productivity to employees

\section{Emotional Exhaustion}

Emotional exhaustion or burn-out is characterized by emotional, physical, and mental fatigue because of persistent and excessive stress. It emerges from a situation that builds constant pressure, strain, and exhausted feeling that one cannot fulfill the demands at the workplace (Cordes \& Dougherty, 1993). Many found that tension builds, the commitment and the value wanes, individuals became less likely motivated to maintain their position to produce the expected results (Maslach, 1982; Maslach \& Jackson, 1981; Raymond \& Ashforth, 1996; Seltzer \& Numerof, 1988). The latest rise in interest in burn-out studies is due to information on this correlation between it and social climate, and distress was reported in the 1970s. Freudenberger (1974) coined the term "burn-out" to refer to the mechanism by which professionals in human service organizations degrade. Burn-out also occurs for various reasons, including when individuals believe they lack the necessary resources, such as time, energy, and support, to meet the workplace's daily demand (Thomas \& Lankau, 2009). Other research describes burn-out as a psychological condition that affects people who interact with other people and who experience physical, mental, and emotional fatigue, depersonalization, and decreased personal achievement (Hunsaker, 2019; Khamisa, Peltzer, \& Oldenburg, 2013; Thomas \& Lankau, 2009; Yang \& Fry, 2018). Thus, identifying the factors that cause burn-out is critical for understanding its predictors and implications, especially in the workplace (Blinded-for-review, 2021a).

In individualist cultures, it is expected that when someone is depressed and emotionally drained, their performance suffers, and concerns about their fit with the job and organization arise (Maslach, Schaufeli, \& Leiter, 2001). Although burn-out has become a global epidemic, the academic focus has remained localized because an overwhelming majority of studies on burn-out have been conducted in the west while other parts of the world, particularly Asia, has trailed far behind (Halbesleben \& Bowler, 2007; Tourigny, Baba, Han, \& Wang, 2013). A decrease in work performance is one of the most often cited adverse effects of emotional exhaustion, while we can say that if employee productivity became a demand, employees might feel stressed and emotional drain happen that way (Boles, Johnston, \& Hair Jr, 1997; Cropanzano, Rupp, \& Byrne, 2003). Their research showed a negative association between work stress and job performance (Halbesleben \& Bowler, 2007; Tourigny et al., 2013). More research needs to be done on the relationship between stress and job performance.

An emotional exhaustion environment diminishes efficiency and depletes resources, leaving individuals increasingly powerless, hopeless, cynical, and resentful. Bobbio, Dierendonck, and Manganelli (2012) 
explained that factors contribute to exhaustion, including position conflict, role tension, a lack of role clarification, an unreasonable workload, increased work pressure, and insufficient supervisory support, i.e., leadership responsibility to cope and manage (Blinded-for-review, 2021a). Specific personality characteristics can affect or influence certain individuals to work in high-stress environments, making them vulnerable, including gender and workplace factors (Armon, Shirom, \& Melamed, 2012; BallengerBrowning et al., 2011).

$\mathrm{H}_{3}$ : Demand for productivity cause emotional exhaustion at the workplace

$\mathrm{H}_{4}$ : Workplace spirituality reduces emotional exhaustion.

Spirituality is different from an individual; religion, prayer, acts, and rituals are often associated with the Transcendent; it is commonly considered a connection to the supernatural, mystical, or a form of faith (Koeing, 2012). Spirituality is also described as "experiences of the spirit in a unique and vibrant process that reflects faith in the God of the highest being, its links to one another, nature and God, and its inclusion of spiritual, organic and spirit aspects (Meraviglia, Sutter, Gaskamp, Adams, \& Titler, 2008) which is essential for their life quality (Edlund, 2014). Spirituality enables direct and devotion, which both serves the faithful life and the achievement of spiritual development (Ashmos \& Duchon, 2000; beneficence.

According to the literature, different appeal in gender differences and emotional life at the workplace has been stated. Females reported more emotional fatigue among the individuals with the disorder (BallengerBrowning et al., 2011). However, another study conducted by psychologists found that women were more likely to be emotionally drained than men (Rupert \& Morgan, 2005). To attempt to discover the inherited buildings, a variety of analyses were performed, each one of which included socio-demographics include gender and workplace social settings taken as independent variables because these different studies have a probability of obtaining a good analysis (Matud, 2004; Michael, Anastasios, Helen, Catherine, \& Christine, 2009; Park, Kim, Cho, \& Han, 2019; Reay, 2004; Richardson \& Woodley, 2003; Soriano, Sarmiento, Songco, Macindo, \& Conde, 2016; Twist \& de Graaf, 2019). Variations in workplace achievement may be assumed to be due to different gender influences and so interpreted accordingly because of this inescapable difference. The facts suggest an "extreme" biological explanation seems impossible, but facts point to a "soft" one because Such findings cannot be explained in terms of biological characteristics. Instead, these results reveal that considerations for research success to shaped by the presence of gender in any setting.

$\mathrm{H}_{5}$ : Socio-demographic differences in organizational life works independently

\section{The rationale of the study and developing path model}

Research in this area is struggling, but there is some evidence that leaders may help to alleviate the problems that occur in the Pakistani education sector (Blinded-for-review, 2020, 2021 b, 2021c) and 
healthcare (Hussain, Hussain, \& Hussain, 2020). This research investigates both education and healthcare sector employees' spiritual development and workplace engagements through workplace spirituality and the degree to which these traits promote performance or productivity, well-being, and reduction of emotional exhaustion.

In the literature review and developed hypothesis, a path model at the core of workplace spirituality and spiritual leadership is an altruistic love that enriches and is encouraged by workplace shared values. These spiritual needs at work meet the positive impact on human strength and psychological well-being. Together spiritual workplace and leadership form the basis for desired outcomes at the workplace. Together, this model answers these pillars with confidence, drive, and commitment; if being taken care of these, an organization could increase the well-being of its members, reduce work dysfunction, and enhance success in social situations; and more manageable to improve performance and happiness within the organization.

\section{Data and procedures}

As it is known, simple random sampling tends to be simpler and more accurate than stratified random sampling for academic non-funding research. There is no more straightforward approach than simple random sampling to obtain a research sample from a wider population. It is unnecessary to split the population into subpopulations or take any further actions beyond plucking subjects at random from the broader population. For estimating causal effects, random experiments are considered the gold standard (Ackerman, Lesko, Siddique, Susukida, \& Stuart, 2021). Thus, the only randomness decides who gets selected, and each member of the larger population has an equal chance of being selected. Kazimierczuk, Zawadzka, and Koźmiński (2009), on the advantages of the random sample, explained that more dimensions are available in this way. The more use of random sampling can be concluded that in contrast to the traditional practice of using a random sample to extract information faster from the same evolution space volume as in conventional experiments. As any data that is available in the order determined and aim for the population would have the implicit assumptions of assuming that the population is either a random or exhaustive in eliminating all biases.

\section{Results And Discussion}

Table 1

\section{Frequencies for Gender}




\begin{tabular}{|llllll|}
\hline Sector & Gender & Frequency & Percent & Valid Percent & Cumulative Percent \\
\hline Health Care & Female & 66 & 59.459 & 59.459 & 59.459 \\
& Male & 45 & 40.541 & 40.541 & 100.000 \\
\hline \multirow{2}{*}{ Education } & Total & 111 & 100.000 & & \\
\hline & Female & 76 & 67.257 & 67.257 & 67.257 \\
& Male & 37 & 32.743 & 32.743 & 100.000 \\
\hline
\end{tabular}

Table 2

\begin{tabular}{|lll|}
\hline \multicolumn{3}{|l|}{ Descriptive Statistics } \\
& & \\
\hline & Gender & \\
\hline & Health Care & Education \\
\hline Valid & 111 & 113 \\
\hline Mean & 1.405 & 1.327 \\
\hline Std. Deviation & 0.493 & 0.471 \\
\hline Minimum & 1.000 & 1.000 \\
\hline Maximum & 2.000 & 2.000 \\
\hline
\end{tabular}

\section{Demographic profile}

To explain the respondents' profile, Table 1 through information about frequencies while Table 2 provides information about descriptive of population. According to Table 2, N-111 noted for health care employees having a mean score of $1.405 \pm$ SD, 0.493 while $N-113$ noted for educational sector employees mean score, $1.327 \pm S D, 0.471$ through no such significant difference in population. Table 1 frequencies explain that $N-66(59.459 \%)$ were females from health care and $N-76(67.257 \%)$ from the education sector participated in the research. At the same time, $\mathrm{N}-45$ (40.541\%) healthcare and $\mathrm{N}-37$ (32.743\%) from education sector male employees participated in this study. Thus, it can be concluded that the participation of female respondents was more overwhelming than males.

Table 3

Model fit and quality indices 


\begin{tabular}{|c|c|}
\hline \multicolumn{2}{|l|}{ Classic indices } \\
\hline Average path coefficient (APC) & $0.221, P<0.001$ \\
\hline Average R-squared (ARS) & $0.173, P=0.002$ \\
\hline Average adjusted R-squared (AARS) & $0.166, P=0.003$ \\
\hline Average block VIF (AVIF) & 1.013 , acceptable if $<=5$, ideally $<=3.3$ \\
\hline Average full collinearity VIF (AFVIF) & 1.456 , acceptable if $<=5$, ideally $<=3.3$ \\
\hline Tenenhaus GoF (GoF) & 0.331, medium $>=0.25$, large $>=0.36$ \\
\hline Sympson's paradox ratio (SPR) & 1.000 , acceptable if $>=0.7$, ideally $=1$ \\
\hline R-squared contribution ratio (RSCR) & 1.000 , acceptable if $>=0.9$, ideally $=1$ \\
\hline Statistical suppression ratio (SSR) & 1.000 , acceptable if $>=0.7$ \\
\hline Nonlinear bivariate causality direction ratio (NLBCDR) & 1.000 , acceptable if $>=0.7$ \\
\hline \multicolumn{2}{|l|}{ Additional indices (indicator corr. matrix fit) } \\
\hline Standardized root mean squared residual (SRMR) & 0.108, acceptable if $<=0.1$ \\
\hline Standardized mean absolute residual (SMAR) & 0.081 , acceptable if $<=0.1$ \\
\hline Standardized chi-squared with 189 DOF (SChs) & 0993, $P<0.001$ \\
\hline Standardized threshold difference count ratio (STDCR) & 0.958, acceptable if $>=0.7$, ideally $=1$ \\
\hline Standardized threshold difference sum ratio (STDSR) & 0.849 , acceptable if $>=0.7$, ideally $=1$ \\
\hline
\end{tabular}

Model fit indices

Wrap-PLS-based structural equation modeling (SEM) software that is exceptionally efficient and essential supports traditional (composite-based) and factor-based PLS algorithms. Identifies nonlinear relationships and calculates path coefficients to avoid curvature in the relationship. It calculates P-values, model fit and consistency indices, and coefficients of maximum collinearity. Warp-PLS is unique among PLS-SEM software in that it provides users with many model-wide fit indices, potentially more than any other SEM software. The model fit indices are of little significance if the aim is to test hypotheses, where each arrow represents a hypothesis. On the other hand, the model fit indices are a valuable collection of measurements related to model quality if the aim is to determine if one model suits the original data better than another (Kock, 2010, 2016). The model fit indices are determined by three of Warp-PLS's primary model fit indices Table 3 are the average path coefficient (APC) $0.221, P<0.001$, the average $R$ squared (ARS) $0.173, P=0.002$, and the average variance inflation factor (AFVIF), $1.013,<=3.3$ explain 
the adequate model fit criterion of this study model presented in Table 3. Additional model fit indices also indicating a comparative good fit model used in this study (Kock, 2017, 2019).

\section{Validity and Reliability}

An empirical evaluation of validity involves investigating the relationship between a specific measure and external benchmarks (both the data produced and subsequent observations). It is referred to as criterionrelated validity, and it is subdivided into four subtypes: convergent, discriminant, concurrent, and predictive validity. While measurement validity seeks to understandability endeavors to discover whether a phenomenon by empirical analysis to discover the phenomenon by investigating the properties a given theory says it should have, measurement should be. There is some quantitative evidence that could be interpreted to conclude that from this data, but it is more using correlational methods and the other statistical methods presented in Tables 4, 5, and 6.

Table 4

Reliabilities

\begin{tabular}{|lllll|}
\hline $\begin{array}{l}\text { Classic and Additional } \\
\text { Reliabilities }\end{array}$ & $\begin{array}{l}\text { Spiritual } \\
\text { Leadership }\end{array}$ & $\begin{array}{l}\text { Workplace } \\
\text { Spirituality }\end{array}$ & Productivity & $\begin{array}{l}\text { Emotional } \\
\text { Exhaustion }\end{array}$ \\
\hline Composite reliability (classic) & 0.898 & 0.885 & 0.92 & 0.899 \\
\hline Cronbach's alpha (classic) & 0.867 & 0.825 & 0.88 & 0.830 \\
\hline $\begin{array}{l}\text { Average Variance Extracted } \\
\text { (classic) }\end{array}$ & 0.560 & 0.658 & 0.732 & 0.747 \\
\hline $\begin{array}{l}\text { Dijkstra's PLSc reliability } \\
\text { (additional) }\end{array}$ & 0.885 & 0.836 & 0.890 & 0.838 \\
\hline Factor reliability (additional) & 0.898 & 0.885 & 0.920 & 0.899 \\
\hline
\end{tabular}

Reliability and validity are woven into many social science disciplines due to the multitude of diverse racial, socioeconomic, and cultural classes studied. Raines-Eudy (2000) explained that structural equation modeling (SEM) techniques provide excellent methods for performing preliminary evaluations of measurement instrument differential validity and reliability across a wide range of population groups. Reasonable reliability and validity are a useful pre-test before survey instruments in the social sciences, considering the growing diversity and multicultural nature. The method may assist in ensuring that study results are not biased by instrument flaws used to measure attitudes, views, beliefs, and other variables that may have varying meanings in different segments of diverse Society (Hair, Black, Babin, \& Anderson, 2010; Hair, Hult, Ringle, \& Sarstedt, 2016; Tucker \& Lewis, 1973; Wülferth, 2013). Table 4 provides information about both classic and additional reliabilities indices obtained through Wrap-PLS according to which $C R \geq .60, A V E \geq .50$, Alpha $\geq .60$ threshold criteria have been achieved (Christmann \& Van Aelst, 2006; House, 1998; Kopalle \& Lehmann, 1997) 
Table 5

Discriminant validity coefficients

\begin{tabular}{|llllll|}
\hline & & 1 & 2 & 3 & 4 \\
\hline 1. & Spiritual Leadership & 0.749 & 0.655 & 0.498 & -0.051 \\
\hline 2. & Workplace Spirituality & 0.655 & 0.811 & 0.383 & 0.056 \\
\hline 3. & Productivity & 0.498 & 0.383 & 0.855 & -0.097 \\
\hline 4. & Emotional Exhaustion & -0.051 & 0.056 & -0.097 & 0.864 \\
\hline
\end{tabular}

Correlations among I.vs. with sq. rts. of AVEs

The HTMT ratios are included in a single cumulative set of outputs and other coefficients useful for evaluating discriminant validity. Correlations between latent variables and square roots of AVEs, structure loadings and cross-loadings, and absolute collinearity VIFs are additional coefficients. Additionally, Table 5 coefficients are used for the HTMT ratios: P-values and 95\% confidence intervals. Coefficients met the desired range of discriminant validity criterion threshold .85 to .90 (Gold, Malhotra, \& Segars, 2001; Hamid, Sami, \& Sidek, 2017; Kline, 2011).

Table 6

Validity and reliability index 


\begin{tabular}{|c|c|c|c|c|c|}
\hline Factor & Label & Loading & $\mathrm{CR}$ & Alpha & Dijkstra's PLSc reliability \\
\hline \multirow[t]{7}{*}{ Spiritual Leadership } & SP1 & 0.801 & \multirow[t]{7}{*}{0.898} & \multirow[t]{7}{*}{0.867} & \multirow[t]{7}{*}{0.872} \\
\hline & SP2 & 0.766 & & & \\
\hline & SP3 & 0.746 & & & \\
\hline & SP4 & 0.804 & & & \\
\hline & SP5 & 0.81 & & & \\
\hline & SP6 & 0.663 & & & \\
\hline & SP7 & 0.629 & & & \\
\hline \multirow[t]{4}{*}{ Workplace Spirituality } & WPS1 & 0.73 & \multirow[t]{4}{*}{0.885} & \multirow[t]{4}{*}{0.825} & \multirow[t]{4}{*}{0.832} \\
\hline & WPS2 & 0.817 & & & \\
\hline & WPS3 & 0.85 & & & \\
\hline & WPS4 & 0.841 & & & \\
\hline \multirow[t]{4}{*}{ Productivity } & PRD1 & 0.845 & \multirow[t]{4}{*}{0.916} & \multirow[t]{4}{*}{0.876} & \multirow[t]{4}{*}{0.885} \\
\hline & PRD2 & 0.898 & & & \\
\hline & PRD3 & 0.905 & & & \\
\hline & PRD4 & 0.766 & & & \\
\hline \multirow[t]{3}{*}{ Emotional Exhaustion } & TOl1 & 0.811 & \multirow[t]{3}{*}{0.899} & \multirow[t]{3}{*}{0.83} & \multirow[t]{3}{*}{0.899} \\
\hline & TOI2 & 0.892 & & & \\
\hline & TOI3 & 0.888 & & & \\
\hline Threshold & & $.60>$ & $.60>$ & $.60>$ & \\
\hline
\end{tabular}

To be considered significant, the variable should have a rotated factor loading of at least $|0.4|$ (meaning +.4 or -.4 ) onto one of the factors (Hair, Anderson, Tatham, \& William, 1998; Peterson, 2000) while 0.6 is a measurable safe range and concrete evidence for consideration without any bias or debate (Hamid et al., 2017). Table 6 throughs factor loading details of each variable factors fulfilling criterion.

Table 7

Path Analysis 


\begin{tabular}{|lllll|}
\hline Path to variables & Coefficient & Effect size & t-Values & p-Values \\
\hline Demographic $\rightarrow$ Spiritual Leadership & -0.149 & 0.022 & -2.296 & 0.011 \\
\hline Demographic $\rightarrow$ Work Spirituality & -0.03 & 0.003 & -0.452 & 0.326 \\
\hline Demographic $\rightarrow$ Productivity & -0.086 & 0.011 & -1.303 & 0.097 \\
\hline Demographic $\rightarrow$ Emotional Exhaustion & -0.227 & 0.048 & -3.534 & $<0.001$ \\
\hline Spiritual Leadership $\rightarrow$ Work Spirituality & 0.657 & 0.434 & 11.073 & $<0.001$ \\
\hline Work spirituality $\rightarrow$ Productivity & 0.375 & 0.144 & 6.005 & $<0.001$ \\
\hline Work spirituality $\rightarrow$ Emotional Exhaustion & 0.125 & 0.015 & 1.907 & 0.029 \\
\hline Productivity $\rightarrow$ Emotional Exhaustion & -0.122 & 0.015 & -1.871 & 0.031 \\
\hline For one-tailed tests: 1.645. IFor two-tailed tests: 1.960. & & & & \\
\hline & $\mathrm{R}^{2}$ & Adj. $\mathrm{R}^{2}$ & $0{ }^{2}$ & VIF s \\
\hline Spiritual Leadership & 0.022 & 0.018 & 0.018 & 2.025 \\
\hline Workplace Spirituality & 0.437 & 0.432 & 1.794 & 0.438 \\
\hline Productivity & 0.154 & 0.147 & 1.353 & 0.162 \\
\hline Emotional Exhaustion & 0.079 & 0.066 & 1.061 & 0.068 \\
\hline
\end{tabular}

Path analysis is used to define the guided dependencies between a collection of variables, and it uses models that are analogous to any form of multiple regression analysis. Path analysis and being a form of multiple regression that focuses on causality can be thought of as a subset of structural equation modeling (SEM) in which only single measures are used for all of the variables in the causal model. According to the hypothesized model of this study presented in figure 1, it was determined that spiritual leadership produces workplace spirituality $\mathrm{H}^{1}$ : which has been accepted as path coefficients of Spiritual leadership 0.657 , effect size 0.434 t-values 11.073 , p-values $<0.001(\leq 0.05)$. $\mathrm{H}^{2}$ : workplace spirituality and productivity path coefficients 0.375 , effect size 0.144 , t-values 0.005 , p-values $<0.001(\leq 0.05)$ validates a significant positive association. Path coefficients workplace spirituality and emotional exhaustion $\mathrm{H}^{3}$ productivity to workplace exhaustion path coefficients 0.125 , effect size 0.015 , $t$-values -1.871 , p-values $0.031,(\leq 0.05)$ indicates an inverse one-tailed relationship thus we can confirm that the inverse relationship exists pertaining productivity demand single dimension cause workplace exhaustion. Workplace spirituality reduces emotional exhaustion $\mathrm{H}^{4}$ path coefficient 0.125 , effect size 0.015 , $\mathrm{t}$-values 1.907 , p-value $0.029(\leq 0.05)$ indicates that workplace spirituality may cause a reduction of emotional exhaustion.

Regarding assumption set about socio-demographics independence, it has been seen that inverse relationship between spiritual leadership path coefficients - -149 , effect size 0.022 , t-values -2.296 -values 
0.011 ( $\leq 0.05$ ) and emotional exhaustion -0.227 effect size 0.048 , t-values -3.534 , p-values $<0.001$ ( $\leq$ 0.05 ) have found significant relationship. In contrast, workplace spirituality and productivity have no relationship with the socio-demographic variables of this study.

According to the literature, $\mathrm{R} 2$ values of $0.67,0.33$, and 0.19 are considered substantial, moderate, and small, respectively (Chin, 1998). The Stone-Geisser Q2 ${ }^{2}$ statistic (Geisser, 1975; Stone, 1974) is often used to determine predictive validity and can be measured using the blindfolding protocol in PLS and concludes that if Q2 values are more significant than 0 , the model is considered to be predictive. Cohen (1988) delves into F2 or effect size Table 7 substantial value $0.02,0.15$, and 0.35 indicates weak, moderate, and high results. This model's most significant effect size has been noted between spirituality and workplace spirituality, followed by workplace spirituality and productivity. In contrast, a moderate value of demographics to spiritual leadership, demographics, productivity, and workplace spirituality to emotional exhaustion has been observed.

\section{Conclusion}

Incorporating spirituality into leadership capacity could make the workplace more friendly and meaningful for followers. Leadership tends to be shifting towards more compassionate, empathetic, and self-empowerment energy approaches because great leadership qualities include assisting the people in discovering the essence and importance of their work and building a connection between them and others. This indicates that leadership spirituality does not include orders and the chain of command, but transformative leadership, which sets the principles of the organization and allows followers to realize that they contribute to a worthy and beneficial aim. Having an organizational focus on spirituality could contribute to increased perceptions of confidence, encouragement, and dedication in the workplace. Spiritual leadership and workplace spirituality were specific objectives examined to determine whether these goals connected to productivity, with members' shared view of the organization's purpose. It was clear that spirituality through appeal to a shared vision is associated with workplace leadership and the public relations team. It concludes that a leader who encompasses workplace spirituality has a greater chance of achieving organizational success. The results could prove beneficial to public relations professionals serving as advisors to new leaders and determining the most efficient channels for organizational productivity challenges. The degree to which an organization can alter, in large part, defines its success or failure. Since leadership styles are among the many factors that transformations occur in an organization, spiritual leadership can bring workplace spirituality culture for everyday appeal. Leadership is a fundamental human phenomenon, just as optimism is. Scholars have traditionally approached the study of leadership from two perspectives: one focusing on positional leadership within an organizational structure and the other on leadership as a collective power mechanism that occurs naturally in social structures. The objective of successful leadership is for the good of all its members and the society in which it exists and participates as partners to achieve its precious organizational objectives. 
Spiritual leadership inculcates workplace spirituality to achieve organizational objectives, bringing productivity and reducing burn-out. Spirituality at work understands that workers have an inner life nourished and nourished by meaningful work in society. It brings a sense of balance between personal and organizational values. Meaningful work and opportunities for inner life are included in the definition of work at the personal level of spirituality. The building of emotional harmony and internal composure strengthened and included the consistency of spirituality at work that reduces exhaustion. Considering this advancement demonstrates that spirituality has a particular significance in science to personal fulfillment, life balance, and mental well-being are all manifestations of spirituality at work.

\section{Limitations and Future direction recommendations}

This study supports the promotion of spiritual leadership in notion and practice. Spiritual leadership is a leadership philosophy that helps organizations and improves community well-being. Spirituality must be held by leaders who govern as a company. Rather than making it a means to an end, spirituality should be a desire to transform the whole enterprise into something of a higher state. Incorporating spirituality into leadership capacity could make the workplace more friendly and meaningful for followers. Having an organizational focus on spirituality could contribute to increased perceptions of confidence, encouragement, and dedication in the workplace. For the authentication of these models, work needs to be done in places like colleges, towns, police, military forces, and for-profit officialdoms with various sample measurements. While Spiritual Leadership theory is being investigated in various settings and cultures, there is a significant research gap in this field (where Spiritual Leadership is being studied in organizational contexts) in South Asian countries such as Pakistan, India, and Sri Lanka, among others.

Results are not generalizable due to demographic limitations. Though spiritual workplace studies have been done in the past, their impact was limited to other demographics (Noor \& Arif, 2011) or specific to physician-only (Jawaid, 2020). This study population is based on two services sectors, i.e., health care and education sector employees from Rawalpindi/Islamabad; considering general health care workers (Pirkola, Rantakokko, \& Suhonen, 2016) in the eastern context of workplace spirituality and spiritual leadership (Weathers, 2018) and education (Schonfeld, Schmid, \& Boucher-Payne, 2016).

\section{Declarations}

We declare that there was no potential conflict of interest reported in this study.

No funding was received to conduct this study.

Informed consent was obtained from respondents to this study.

\section{References}


Abdullah, A. G. K., Alzaidiyeen, N. J., \& Aldarabah, I. T. (2009). Workplace spirituality and leadership effectiveness among educational managers in Malaysia. European Journal of Social Sciences, 10(2), 304-316.

Ackerman, B., Lesko, C. R., Siddique, J., Susukida, R., \& Stuart, E. A. (2021). Generalizing randomized trial findings to a target population using complex survey population data. Statistics in Medicine, 40(5), 11011120. https://doi.org/10.1002/sim. 8822

Afsar, B., Badir, Y., \& Kiani, U. S. (2016). Linking spiritual leadership and employee pro-environmental behavior: The influence of workplace spirituality, intrinsic motivation, and environmental passion. Journal of Environmental Psychology, 45, 79-88. https://doi.org/10.1016/j.jenvp.2015.11.011

Armon, G., Shirom, A., \& Melamed, S. (2012). The big five personality factors as predictors of changes across time in burnout and its facets. Journal of personality, 80(2), 403-427. https://doi.org/10.1111/j.1467-6494.2011.00731.x

Armstrong-Stassen, M., \& Schlosser, F. (2011). Perceived organizational membership and the retention of older workers. Journal of organizational behavior, 32(2), 319-344. https://doi.org/10.1002/job.647

Ashmos, D. P., \& Duchon, D. (2000). Spirituality at work: A conceptualization and measure. Journal of management inquiry, 9(2), 134-145. https://doi.org/10.1177/105649260092008

Ballenger-Browning, K. K., Schmitz, K. J., Rothacker, J. A., Hammer, P. S., Webb-Murphy, J. A., \& Johnson, D. C. (2011). Predictors of burnout among military mental health providers. Military medicine, 176(3), 253260. https://doi.org/10.7205/MILMED-D-10-00269

Benefiel, M. (2005). The second half of the journey: Spiritual leadership for organizational transformation. The leadership quarterly, 16(5), 723-747. https://doi.org/10.1016/j.leaqua.2005.07.005

Benefiel, M., Fry, L. W., \& Geigle, D. (2014). Spirituality and religion in the workplace: History, theory, and research. Psychology of Religion and Spirituality, 6(3), 175-187. https://doi.org/10.1037/a0036597

Blackaby, H. T., \& Blackaby, R. (2011). Spiritual leadership: Moving people on to God's agenda. Nashville, Tennessee: B\&H Publishing Group.

Blinded-for-review. (2020). Positive Leadership Psychology.

Blinded-for-review. (2021a). Individual Psychological Distance: Leadership Task.

Blinded-for-review. (2021b). Servant leadership A Strategic Choice.

Blinded-for-review. (2021c). Spiritual leadership.

Bobbio, A., Dierendonck, D. V., \& Manganelli, A. M. (2012). Servant leadership in Italy and its relation to organizational variables. Leadership, 8(3), 229-243. https://doi.org/10.1177/1742715012441176 
Boles, J. S., Johnston, M. W., \& Hair Jr, J. F. (1997). Role stress, work-family conflict and emotional exhaustion: Inter-relationships and effects on some work-related consequences. Journal of Personal Selling and Sales Management, 17(1), 17-28.

Cash, K. C., \& Gray, G. R. (2000). A framework for accommodating religion and spirituality in the workplace. Academy of Management Perspectives, 14(3), 124-133.

https://doi.org/10.5465/ame.2000.4468072

Chen, C.-Y., Chen, C.-H. V., \& Li, C.-I. (2013). The influence of leader's spiritual values of servant leadership on employee motivational autonomy and eudaemonic well-being. Journal of religion health, 52(2), 418438. https://doi.org/10.1007/s10943-011-9479-3

Chen, C.-Y., \& Yang, C.-F. (2012). The impact of spiritual leadership on organizational citizenship behavior: A multi-sample analysis. Journal of Business Ethics, 105(1), 107-114. https://doi.org/10.1007/s10551011-0953-3

Chin, W. W. (1998). The partial least squares approach to structural equation modeling. In G. A. Marcoulides (Ed.), Modern Methods for Business Research: Quantitative Methodology Series (Vol. 2, pp. 295-336). Mahwah, NJ USA: Lawrence Erlbaum Associates.

Christmann, A., \& Van Aelst, S. (2006). Robust estimation of Cronbach's alpha. Journal of Multivariate Analysis, 97(7), 1660-1674.

Cohen, J. (1988). Statistical Power Analysis for the Behavioral Sciences. In (2 ${ }^{\text {nd }}$ ed.). Hillsdale, NJ, USA: Lawrence Erlbaum Associates.

Collins, R. D. (2010). Designing ethical organizations for spiritual growth and superior performance: An organization systems approach. Journal of Management, Spirituality Religions, 7(2), 95-117.

https://doi.org/10.1080/14766081003746414

Cordes, C. L., \& Dougherty, T. W. (1993). A review and an integration of research on job burnout. Academy of management review, 18(4), 621-656. https://doi.org/10.5465/amr.1993.9402210153

Cropanzano, R., Rupp, D. E., \& Byrne, Z. S. (2003). The relationship of emotional exhaustion to work attitudes, job performance, and organizational citizenship behaviors. Journal of applied psychology, 88(1), 160. https://doi.org/10.1037/0021-9010.88.1.160

Edlund, B. J. (2014). Revisiting spirituality in aging. Journal of Gerontological Nursing, 40(7), 4-5. https://doi.org/10.3928/00989134-20140618-01

Freeman, G. (2011). Spirituality and servant leadership: A conceptual model and research proposal. Emerging leadership journeys, 4(1), 120-140. 
Freudenberger, H. J. (1974). Staff burn-out. Journal of social issues, 30(1), 159-165.

https://doi.org/10.1111/j.1540-4560.1974.tb00706.x

Fry, L. W. (2003). Toward a theory of spiritual leadership. The leadership quarterly, 14(6), 693-727. https://doi.org/10.1016/j.leaqua.2003.09.001

Fry, L. W., \& Cohen, M. P. (2009). Spiritual leadership as a paradigm for organizational transformation and recovery from extended work hours cultures. Journal of Business Ethics, 84(2), 265-278.

https://doi.org/10.1007/s10551-008-9695-2

Fry, L. W., Latham, J. R., Clinebell, S. K., \& Krahnke, K. (2017). Spiritual leadership as a model for performance excellence: a study of Baldrige award recipients. Journal of Management, Spirituality Religion, 14(1), 22-47. https://doi.org/10.1080/14766086.2016.1202130

Fry, L. W., \& Nisiewicz, M. S. (2013). Maximizing the triple bottom line through spiritual leadership. Redwood City, California, USA: Stanford University Press.

Fry, L. W., Vitucci, S., \& Cedillo, M. (2005). Spiritual leadership and army transformation: Theory, measurement, and establishing a baseline. The leadership quarterly, 16(5), 835-862.

https://doi.org/10.1016/j.leaqua.2005.07.012

Geisser, S. (1975). The predictive sample reuse method with applications. Journal of the American Statistical Association, 70(350), 320-328.

Giacalone, R., Jurkiewicz, C., \& Fry, L. (2005). From advocacy to science: The Next Steps in Workplace Spirituality Research. In R. F. Paloutzian \& C. L. Park (Eds.), Handbook of The Psychology of Religion and Spirituality (pp. 515-528). New York, NY, USA: The Guilford Press.

Giacalone, R. A., \& Jurkiewicz, C. L. (2010). The science of workplace spirituality (3, revised ed. Vol. 2). New York, USA: Routledge.

Gold, A. H., Malhotra, A., \& Segars, A. H. (2001). Knowledge management: An organizational capabilities perspective. Journal of management information systems, 18(1), 185-214.

https://doi.org/10.1080/07421222.2001.11045669

Hair, J. F., Anderson, R. E., Tatham, R. L., \& William, C. (1998). Multivariate Data Analysis. In J. F. Hair (Ed.), ( $5^{\text {th }}$ ed.). New Jersey, USA: Prentice-Hall, Upper Saddle River

Hair, J. F., Black, W. C., Babin, B. J., \& Anderson, R. E. (2010). Multivariate Data Analysis: A Global Perspective. In New Jersey, USA ( $7^{\text {th }}$ ed.). Upper Saddle River, : Pearson Prentice-Hall.

Hair, J. F., Hult, G. T. M., Ringle, C., \& Sarstedt, M. (2016). A Primer on Partial Least Squares Structural Equation Modeling (PLS-SEM). (2nd ed.). New York, USA: Sage Publications. 
Halbesleben, J. R., \& Bowler, W. (2007). Emotional exhaustion and job performance: the mediating role of motivation. Journal of applied psychology, 92(1), 93-106. https://doi.org/10.1037/0021-9010.92.1.93

Hamid, M. R. B. A., Sami, W., \& Sidek, M. M. (2017). Discriminant validity assessment: Use of Fornell \& Larcker criterion versus HTMT criterion. Journal of Physics: Conference Series, 890(1), 1-5 (012163). https://doi.org/10.1088/1742-6596/890/1/012163

Hill, P. C., \& Edwards, E. (2013). Measurement in the psychology of religiousness and spirituality: Existing measures and new frontiers. In K. I. Pargament, J. J. Exline, \& J. W. Jones (Eds.), APA handbook of psychology, religion, and spirituality (Vol. 1): American Psychological Association.

Hitt, M. A., \& Duane, R. (2002). The essence of strategic leadership: Managing human and social capital. Journal of Leadership Organizational Studies, 9(1), 3-14. https://doi.org/10.1177/107179190200900101 Hood, R. W. (2005). Mystical, spiritual, and religious experiences. Handbook of the psychology of religion spirituality, 348-364.

House, R. J. (1998). Measures and assessments for the charismatic leadership approach: Scales, latent constructs, loadings, Cronbach alphas, and interclass correlations. Monographs in Organizational Behavior Industrial Relations, 24, 23-30.

Hunsaker, W. (2019). Spiritual leadership and job burnout: Mediating effects of employee well-being and life satisfaction. Management Science Letters, 9(8), 1257-1268. https://doi.org/10.5267/j.msl.2019.4.016 Hussain, S., Hussain, Z., \& Hussain, S. (2020). Workplace Spirituality And Turnover Intentions Among The Doctors Working In Private Hospitals In Karachi, Pakistan: A Cross Sectional Study. British Journal of Medical \& Health Sciences, 2(8), 402-407.

Jawaid, H. (2020). Assessing Perception of Patients and Physicians Regarding Spirituality in Karachi, Pakistan: A Pilot Study. The Permanente Journal, 24. https://doi.org.10.7812/TPP/19.214

Judge, T. A., Bono, J. E., Ilies, R., \& Gerhardt, M. W. (2002). Personality and leadership: a qualitative and quantitative review. Journal of applied psychology, 87(4), 765. https://doi.org.10.1037//00219010.87.4.765

Karadag, E. (2009). Spiritual Leadership and Organizational Culture: A Study of Structural Equation Modeling. Educational Sciences: Theory Practice, 9(3), 1391-1405. https://EJ858928

Kazimierczuk, K., Zawadzka, A., \& Koźmiński, W. (2009). Narrow peaks and high dimensionalities: exploiting the advantages of random sampling. Journal of Magnetic Resonance, 197(2), 219-228. https://doi.org/10.1016/j.jmr.2009.01.003

Khamisa, N., Peltzer, K., \& Oldenburg, B. (2013). Burnout in relation to specific contributing factors and health outcomes among nurses: a systematic review. International journal of environmental research in 
public health, 10(6), 2214-2240. https://doi.org/10.3390/ijerph10062214

Kline, R. (2011). Principles and practice of structural equation modeling (4th editions). New York: Guilford Publications, Inc.

Kock, N. (2010). Using WarpPLS in e-collaboration studies: An overview of five main analysis steps. International Journal of e-Collaboration, 6(4), 1-11. https://doi.org.10.4018/jec.2010100101

Kock, N. (2016). Advantages of nonlinear over segmentation analyses in path models. International Journal of e-Collaboration, 12(4), 1-6. https://doi.org.10.4018/IJeC.2016100101

Kock, N. (2017). Structural equation modeling with factors and composites: A comparison of four methods. International Journal of e-Collaboration, 13(1), 1-9. https://doi.org.10.4018/IJeC.2017010101

Kock, N. (2019). Factor-based structural equation modeling with WarpPLS. Australasian Marketing Journal, 27(1), 57-63. https://doi.org/10.1016/j.ausmj.2019.02.002

Koeing, H. (2012). Religion, spirituality, and health: The research and clinical implications. International Scholarly Research Network, 2012(33), 278730. http://dx.doi.org/10.5402/2012/278730

Kopalle, P. K., \& Lehmann, D. R. (1997). Alpha inflation? The impact of eliminating scale items on Cronbach's alpha. Organizational behavior human decision processes, 70(3), 189-197. https://doi.org/10.1006/obhd.1997.2702

Lewis, J. S., \& Geroy, G. D. (2000). Employee spirituality in the workplace: A cross-cultural view for the management of spiritual employees. Journal of Management Education, 24(5), 682-694.

https://doi.org/10.1177/105256290002400510

Maslach, C. (1982). Burnout: The cost of caring. . In PrenticeHal (Ed.). New York: .

Maslach, C., \& Jackson, S. E. (1981). The measurement of experienced burnout. Journal of organizational behavior, 2(2), 99-113. https://doi.org/10.1002/job.4030020205

Maslach, C., Schaufeli, W. B., \& Leiter, M. P. (2001). Job burnout. Annual Review of Psychology, 52(1), 397422. https://doi.org/10.1146/annurev.psych.52.1.397

Matud, M. P. (2004). Gender differences in stress and coping styles. Personality individual differences, 37(7), 1401-1415. https://doi.org/10.1016/j.paid.2004.01.010

Meng, Y. (2016). Spiritual leadership at the workplace: Perspectives and theories. Biomedical reports, 5(4), 408-412. https://doi.org.10.3892/br.2016.748

Meraviglia, M., Sutter, R., Gaskamp, C. D., Adams, S., \& Titler, M. G. (2008). Providing spiritual care to terminally ill older adults. Journal of Gerontological Nursing, 34(7), 8-14.

https://doi.org/10.3928/00989134-20080701-08

Page 20/24 
Michael, G., Anastasios, S., Helen, K., Catherine, K., \& Christine, K. (2009). Gender differences in experiencing occupational stress: the role of age, education and marital status. Stress Health: Journal of the International Society for the Investigation of Stress, 25(5), 397-404. https://doi.org/10.1002/smi.1248

Mubashar, U.-e.-F., Salman, Y., Irfan, S., \& Jabeen, N. (2017). Spiritual leadership in organizational context: A research gap in South Asia. South Asian Studies, 32(1), 205-218.

Nahardani, S. Z., Ahmadi, F., Bigdeli, S., \& Arabshahi, K. S. (2019). Spirituality in medical education: A concept analysis. Medicine, Health Care Philosophy, 22(2), 179-189. https://doi.org/10.1111/j.13652702.2010.03547.x.

Noor, S., \& Arif, S. (2011). Achieving job satisfaction via workplace spirituality: Pakistani doctors in focus. European Journal of Social Sciences, 19(4), 507-515.

Northouse, P. G. (2010). Leadership: Theory and practice ( $5^{\text {th }}$ ed.). Thousand Oaks, CA, USA: SAGE Publications, Incorporated.

Oh, J., \& Wang, J. (2020). Spiritual leadership: current status and Agenda for future research and practice. Journal of Management, Spirituality Religion, 1-26. https://doi.org/10.1080/14766086.2020.1728568

Park, C., Kim, D.-g., Cho, S., \& Han, H.-J. (2019). Adoption of multimedia technology for learning and gender difference. Computers in Human Behavior., 92, 288-296.

https://doi.org/10.1016/j.chb.2018.11.029

Peltonen, T. (2017). Spirituality and religion in organizing: Beyond secular leadership: Springer.

Peterson, R. A. (2000). A meta-analysis of variance accounted for and factor loadings in exploratory factor analysis. Marketing letters, 11(3), 261-275. https://doi.org.10.1023/A:1008191211004

Pirkola, H., Rantakokko, P., \& Suhonen, M. (2016). Workplace spirituality in health care: An integrated review of the literature. Journal of nursing management, 24(7), 859-868.

https://doi.org/10.1111/jonm.12398

Raines-Eudy, R. (2000). Using structural equation modeling to test for differential reliability and validity: An empirical demonstration. Structural equation modeling: a multidisciplinary journal, 7(1), 124-141. https://doi.org/10.1207/S15328007SEM0701_07

Raymond, L. T., \& Ashforth, B. E. (1996). A meta-analytic examination of the correlates of the three dimensions of job burnout. Journal of applied psychology, 81(2), 123-133. https://doi.org/10.1037/00219010.81.2.123

Reay, D. (2004). Gendering Bourdieu's concepts of capitals? Emotional capital, women and social class. The sociological review, 52(2_suppl), 57-74. https://doi.org/10.1111/j.1467-954X.2005.00524.x 
Richardson, J. T., \& Woodley, A. (2003). Another look at the role of age, gender and subject as predictors of academic attainment in higher education. Studies in Higher Education, 28(4), 475-493. https://doi.org/10.1080/0307507032000122305

Rouhoma, H. M., Dhar, B. K., Ali, K., \& Osman, M. M. (2018). Constructing model to explore the influence of Religiosity and Spirituality on Organizational Performance through Organizational Commitment. AL'ABQARI: Journal of Islamic Social Sciences Humanities, 16, 11-30.

Rupert, P. A., \& Morgan, D. J. (2005). Work setting and burnout among professional psychologists. Professional Psychology: Research andPractice, 36(5), 544-550. https://doi.org/10.1037/07357028.36.5.544

Sani, A., Soetjipto, B. E., \& Maharani, V. (2016). The effect of spiritual leadership on workplace spirituality, job satisfaction and ihsan behaviour (a study on nurses of aisyiah Islamic hospital in Malang, Indonesia). International Journal of Applied Business Economic Research, 14(11), 7675-7688.

Schonfeld, T. L., Schmid, K. K., \& Boucher-Payne, D. (2016). Incorporating spirituality into health sciences education. Journal of Religion and Health, 55(1), 85-96. https://doi.org.10.1007/s10943-014-9972-6

Seltzer, J., \& Numerof, R. E. (1988). Supervisory leadership and subordinate burnout. Academy of Management journal, 31(2), 439-446. https://doi.org/10.5465/256559

Seong, J. Y., \& Hong, D. S. (2018). Age diversity, group organisational citizenship behaviour, and group performance: Exploring the moderating role of charismatic leadership and participation in decisionmaking. Human resource management journal, 28(4), 621-640. https://doi.org/10.1111/17488583.12197

Sholikhah, Z., Wang, X., \& Li, W. (2019). The role of spiritual leadership in fostering discretionary behaviors: The mediating effect of organization based self-esteem and workplace spirituality. International Journal of Law Management, 61(1), 232-249. https://doi.org/10.1108/IJLMA-04-2018-0081

Sohail, M. M., Mahmood, Q. K., Sher, F., Saud, M., Mas'udah, S., \& Ida, R. (2019). Coping Through Religiosity, Spirituality and Social Support Among Muslim Chronic Hepatitis Patients. Journal of religion health, 1-15. https://doi.org/10.1007/s10943-019-00909-4

Soriano, C. A. F., Sarmiento, W. D., Songco, F. J. G., Macindo, J. R. B., \& Conde, A. R. (2016). Sociodemographics, spirituality, and quality of life among community-dwelling and institutionalized older adults: A structural equation model. Archives of Gerontology and Geriatrics, 66, 176-182. https://doi.org/10.1016/j.archger.2016.05.011

Stone, M. (1974). Cross-validatory choice and assessment of statistical predictions. Journal of the Royal Statistical Society: Series B, 36(2), 111-133. https://doi.org/10.1111/j.2517-6161.1974.tb00994.x 
Stylianou, A., \& Zembylas, M. (2019). Head teachers' spirituality and inclusive education: a perspective from critical realism. International Journal of Inclusive Education, 23(4), 419-435.

https://doi.org/10.1080/13603116.2018.1441336

Sun, F., \& Hodge, D. (2012). Positive aspects of caregiving among Alzheimer's family caregivers: The roles of ethnicity and spirituality. Paper presented at the Presented at the16th Annual Scientific Meeting of the Society for Social Work and Research.

Thomas, C. H., \& Lankau, M. J. (2009). Preventing burnout: The effects of LMX and mentoring on socialization, role stress, and burnout. Human Resource Management, 48(3), 417-432.

https://doi.org/10.1002/hrm.20288

Timmins, F., \& Martin, C. (2019). Spirituality and locus of control-A rapid literature review. Spirituality in Clinical Practice, 6(2), 83-99. https://doi.org/10.1037/scp0000192

Tischler, L., Biberman, J., \& McKeage, R. (2002). Linking emotional intelligence, spirituality and workplace performance. Journal of managerial Psychology, 17(3), 203-218.

https://doi.org/10.1108/02683940210423114

Tourigny, L., Baba, V. V., Han, J., \& Wang, X. (2013). Emotional exhaustion and job performance: the mediating role of organizational commitment. The International Journal of Human Resource Management, 24(3), 514-532. https://doi.org/10.1080/09585192.2012.694109

Tucker, L. R., \& Lewis, C. (1973). A reliability coefficient for maximum likelihood factor analysis. Psychometrika, 38(1), 1-10. https://doi.org/10.1007/BF02291170

Twist, J., \& de Graaf, N. M. (2019). Gender diversity and non-binary presentations in young people attending the United Kingdom's National Gender Identity Development Service. Clinical Child Psychology and Psychiatry, 24(2), 277-290. https://doi.org/10.1177/1359104518804311

Weathers, E. (2018). Spirituality and health: A Middle Eastern perspective. Religions, 9(2), 33. https://doi.org/10.3390/rel9020033

Woods, G. (2007). The 'Bigger Feeling' The Importance of Spiritual Experience in Educational Leadership. Educational Management Administration Leadership, 35(1), 135-155.

https://doi.org/10.1177/1741143207071390

Wootton, S., \& Horne, T. (2010). Strategic thinking: A step-by-step approach to strategy and leadership. London, UK: Kogan Page Publishers.

Worden, S. (2005). Religion in strategic leadership: A positivistic, normative/theological, and strategic analysis. Journal of Business Ethics, 57(3), 221-239. https://doi.org/10.1007/s10551-004-6943-y 
Wülferth, H. (2013). Validity and Reliability of Empirical Discretion Model. In Managerial Discretion and Performance in China (pp. 257-368). Physica, Berlin, Heidelberg: Springer.

Yang, M., \& Fry, L. W. (2018). The role of spiritual leadership in reducing healthcare worker burnout. Journal of Management, Spirituality Religion, 15(4), 305-324.

https://doi.org/10.1080/14766086.2018.1482562

\section{Figures}

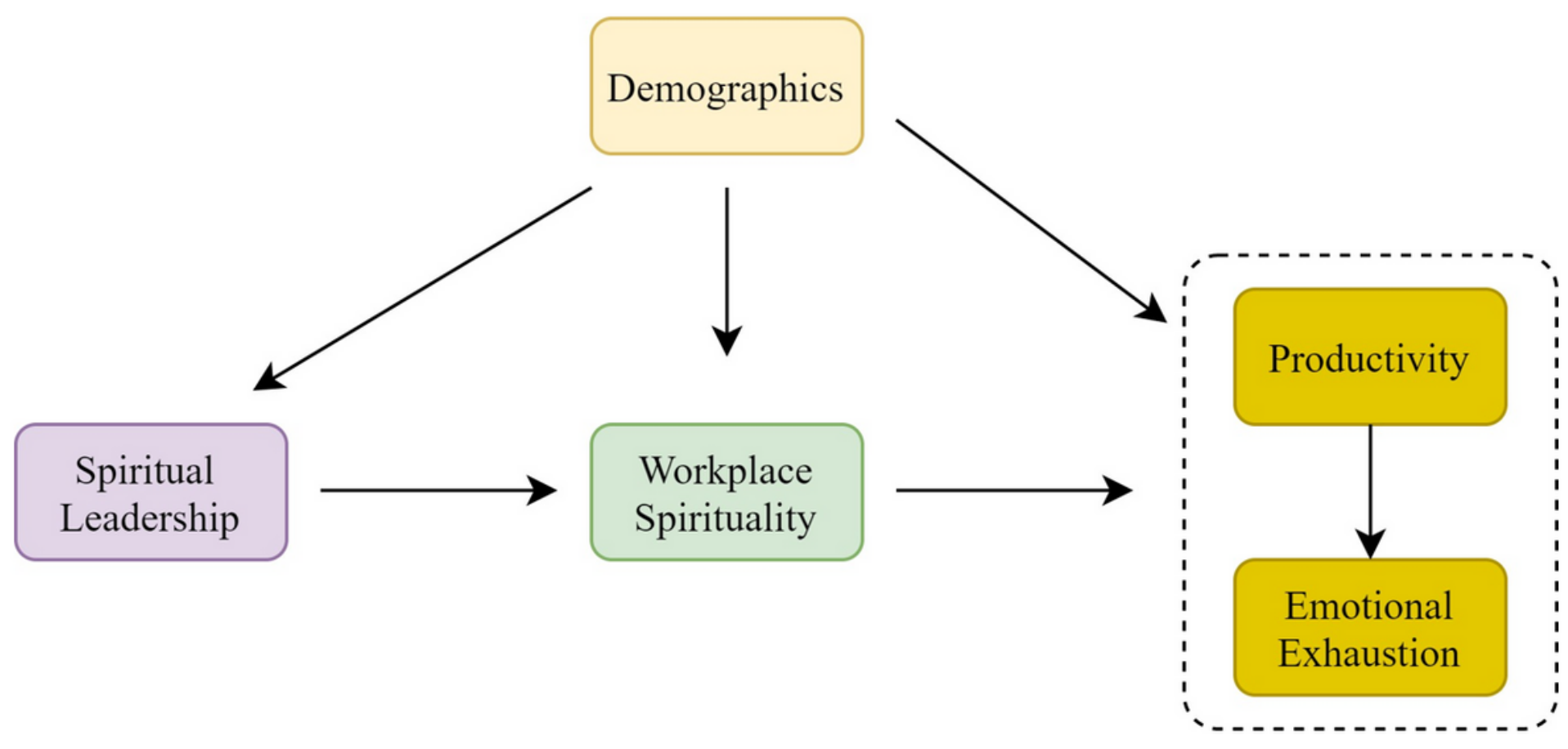

Figure 1

Path Model of conceptual framework 